I den arabiske verden får den moderne livsform ofte skylden for depression og selvmord. Muslimer går dermed angiveligt fri, for islam giver livet det indhold, mennesket behøver.

\title{
Depression og selvmord i den arabiske verden
}

Gunna Funder Hansen er ph.d. og adjunkt ved Center for Mellemøststudier, Syddansk Universitet. Hun forsker i sprogpædagogik og arabisk og arbejder også med aspekter vedrørende etniske minoriteter i social-, sundheds- og uddannelsessektoren. 
TEKST: Gunna Funder Hansen

DEPRESSION ER EN ret almindelig sygdom, hvis primære symptomer er melankoli, skyldfølelse, lavt selvværd, søvnforstyrrelser, appetitløshed, apati og dårlig koncentration. Problemerne kan blive kroniske og føre til, at den syge ikke magter at passe et job og tage vare på sig selv og sine nærmeste. Derfor klassificerer WHO også depression som et handicap - et af de mest udbredte af slagsen på verdensplan. Ifølge WHO og Verdensbanken rammes omkring 20 procent af alle mennesker af depression på et eller andet tidspunkt i deres liv. I sidste instans er sygdommen livsfarlig, idet den - hvis den ikke behandles - kan føre til selvmord.

Samtidig forventes problemerne med depression at stige i de kommende år. I dag overhales lidelsen kun af hjerte-kar-sygdomme, men snart vil depression ifølge
WHO være den mest udbredte folkesygdom overhovedet, mens selvmord i 2020 som resultat heraf vil være nr. to på listen over årsager til dødsfald. ${ }^{2}$ Der kan ikke gives en entydig forklaring på hvorfor, men blandt de fremherskende forklaringsmodeller er hypoteser om, at det postmoderne samfund og det opbrud i kulturer og traditioner, som vi i gennemlever, bærer en stor del af skylden. Det er åbenbart blevet sværere at være menneske.

Desuden synes der at være en stigende tilbøjelighed til, at man søger behandling for sin depression, hvilket gør problemet mere synligt. Dette skyldes sandsynligvis at forskningen har afdækket, at depression ofte skyldes mangel på signalstoffet serotonin i hjernen, og at serotoninbalancen $\mathrm{i}$ dag kan genoprettes med medicin. ${ }^{3}$ Depression er dermed blevet mere anerkendt som noget, der kan ramme os alle, og tusindvis af patienter, der tidligere måtte acceptere depressionen eller tage psykofarmaka med heftige bivirkninger, kan i dag leve et normalt liv. Alligevel skønner Psykiatrifonden i Danmark, at omkring Io0.000 danskere lider af ubehandlet eller mangelfuldt behandlet depression - hvilket har alvorlige sociale konsekvenser i form af for eksempel problemer i familien og på arbejdspladsen og store økonomiske tab for samfundet på grund af uarbejdsdygtighed. ${ }^{4}$

Men hvordan ser billedet ud i den arabiske verden, hvor psykiske sygdomme generelt har været endnu mere tabubelagte end i Danmark, og hvor selvmord ofte opfattes som et ikke-eksisterende problem?

\section{Tabu i opbrud?}

Psykiske sygdomme er generelt voldsomt tabuiserede i den arabiske verden. Imidlertid synes der i de senere år - især i 
Maghreb-landene, hvor sundhedsvæsenet normalt har tætte uddannelses- og samarbejdsmæssige forbindelser til Frankrig - at være skabt en ny åbenhed omkring depression. Således er salget af antidepressive midler i Marokko steget med 48 procent mellem I999 og 2004, ${ }^{5}$ ligesom psykiatriske lidelser og problemer med selvmord på forskellige måder er blevet eksponeret i pressen. ${ }^{6}$ Samtidig er professionelle psykiatere begyndt at gennemføre videnskabelige undersøgelser af, hvor udbredt depression og selvmord faktisk er, og hvordan folk forholder sig til disse fænomener.

\section{De fleste opfatter et andet menneskes depression som et tegn på dovenskab og svigtende tro på Gud.}

I 2005 påbegyndte det marokkanske sundhedsministerium en stor undersøgelse med en population på 5500 individer men det er den første undersøgelse af sin art på det afrikanske kontinent nogensinde.

Ifølge tre af de marokkanske psykiatere og forskere, der står for undersøgelsen, lider I3-I7 procent af marokkanerne af depression, men uden for det psykiatriske, lægelige miljø er lidelsen stærkt tabuiseret. Deres foreløbige resultater viser, at det er en ganske udbredt forestilling blandt muslimer, at mennesker, der lever i et muslimsk miljø slet ikke rammes af depression. Eftersom troen giver mennesket forklaringen på livet og alle nødvendige retningslinjer for, hvordan det skal leves, er den livstræthed, som depression opfattes som et udtryk for, ikke accepteret. Depression opfattes derfor af mange muslimer ligefrem som værende haram - eller religiøst forbudt - idet det ses som udtryk for manglende accept af den skæbne, man nu en gang fra Guds hånd har fået tildelt. De fleste opfatter et andet menneskes depression som et tegn på "overforkælelse", dovenskab, manglende viljestyrke - og svigtende tro på Gud.?

\section{Forskellige symptomer}

Et resultat af denne holdning til depression er, at den syge gør alt for at skjule sin indre lidelse, mens de fysiske symptomer bliver centrale, idet de er lettere at tage og føle på og lettere anerkendes af omgivelserne. Og det er formentlig baggrunden for, at man i tværkulturelle studier af psykiske sygdomme finder en forskel i symptomer og hvordan patienter redegør for dem. Eksempelvis viser studier fra Emiraterne med endogen depression - det vil sige akut depression, der opstår uden en umiddelbar udløsende faktor - at patienter i Emiraterne definerer deres melankoli meget anderledes end de vestlige patienter. De vestlige patienter fremhæver især problemer med skyldfølelse og lav libido, hvilket sjældent nævnes af de arabiske depressive, som til gengæld i modsætning til de vestlige ofte bruger somatiske metaforer til at udtrykke deres "mentale smerte". Hos de arabiske patienter indgår religiøse elementer $\mathrm{i}$ vid udstrækning, når symptomerne forklares, og ofte manifesterer depressionen sig i symptomer eller adfærd, der normalt slet ikke associeres med sygdommen i en vestlig kontekst. ${ }^{8}$ Eksempelvis opleves og beskrives depression ofte som ubehag eller smerte et sted i kroppen,

Endogen depression er mest utbredt blant kvinder. 
babylon 11 : babylon5 26-03-08 $02: 17$ Side 45

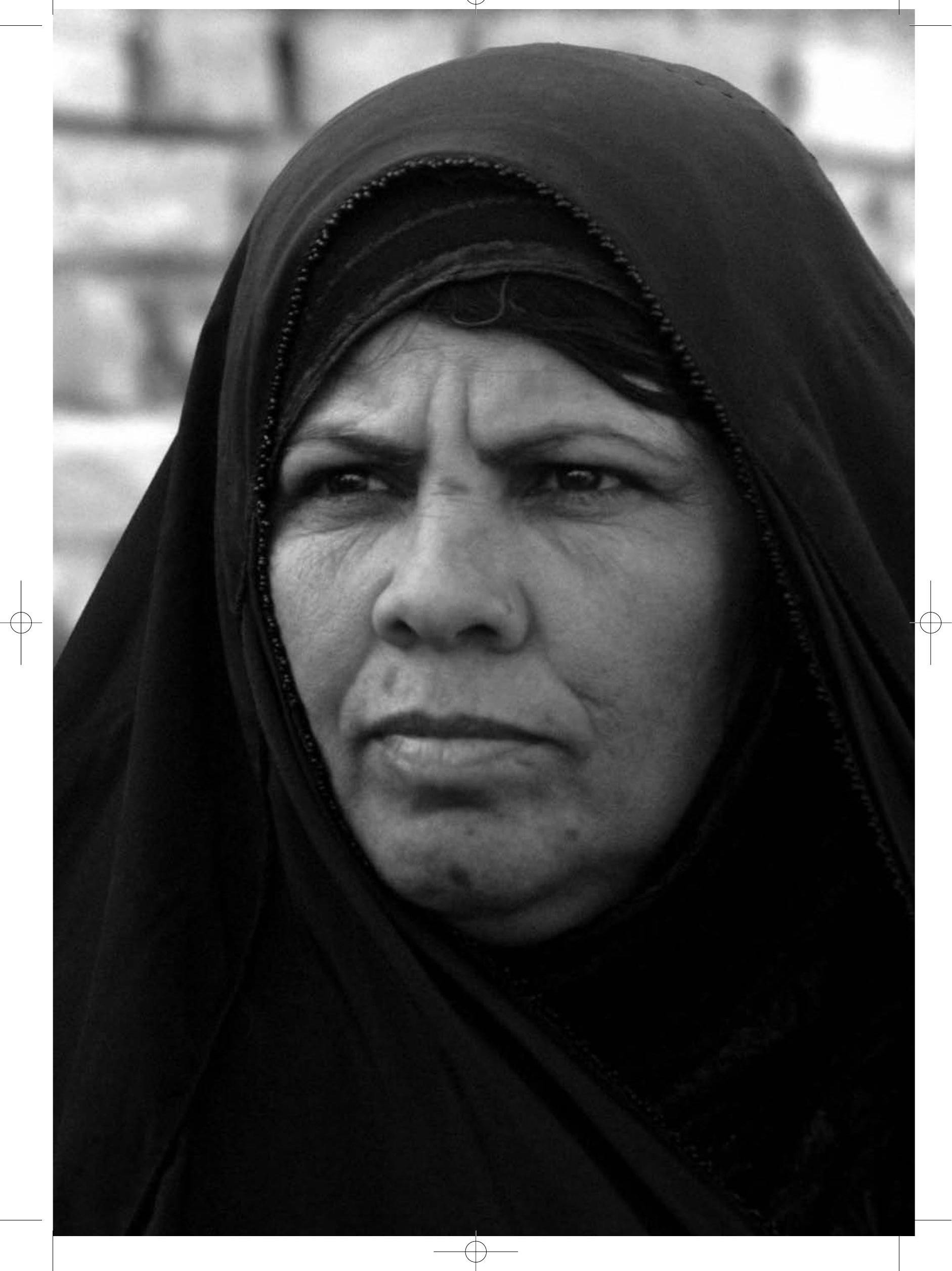


og onde ånder er en almindelig anvendt forklaringsmodel. Ligeledes fandt de førnævnte marokkanske psykiatere, at den manglende libido, der ofte følger med en depression, kun sjældent associeres med depressionen. Hos mænd opfattes det derimod gerne som en slags forbandelse, der er nedkastet over dem, hvorfor de går til en faqih for at søge hjælp til at få forbandelsen ophævet.

Samtidig er det et problem, at selv hvis man søger hjælp hos en læge fremfor hos en religiøs autoritet eller heksekunstner, får man ikke nødvendigvis den rette behandling. En kvalitativ undersøgelse af jordanske lægers holdninger og behandlingsmetoder $\mathrm{i}$ relation til depression viser en slående mangel på basal viden om sygdommen og de moderne behandlingsmetoder i den primære behandlingssektor, ${ }^{9}$ ligesom de førnævnte marokkanske psykiatere påpeger, at alment praktiserende læger i Marokko er alt for dårligt uddannede inden for psykiatri. Og selv hvis lægen indser dette og helst henviser til en specialist, skal man være heldigt stillet både geografisk og økonomisk for at få den kombination af medicinsk og terapeutisk behandling, som har den dokumenteret bedste effekt. Eksempelvis råder Marokko over blot 300 psykiatere og I50 psykoterapeuter, og de er alle geografisk placeret i området omkring Casablanca og Rabat. ${ }^{\text {Io }}$ Samtidig koster en konsultation omkring 300 dirham, mens en månedsløn ligger omkring 1500 dirham for en ufaglært og omkring 2500-3000 dirham for en højtuddannet offentlig ansat $i$ en underordnet stilling. Dermed er behandling hos privatpraktiserende behandlere i praksis uden for rækkevidde for de fleste marokkanere.
Hertil kommer, at de psykiatriske afdelinger på hospitalerne rundt om i landet er stærkt underbemandede, ligesom antallet af sengepladser er særdeles begrænset. Mange steder har man slet ikke uddannede psykiatere, og der er derfor meget stor forskel på kvaliteten af behandlingen på de forskellige afdelinger. Mens de store hospitaler i hovedstadsområdet måske kan tilbyde en tidssvarende behandling, findes der stadig psykiatriske institutioner - i Marokko som i resten af den arabiske verden - hvor de psykisk syge opbevares og lægges i lænker, og hvor behandlingen fortrinsvis består i djævleuddrivelse - som i praksis kan tage form af torturmetoder - suppleret med ofring af for eksempel kyllinger og lam. Denne form for behandling går oftest ud over patienter med skizofreni eller psykoser, men det illustrerer, at moderne psykiatrisk behandling langt fra er en selvfølge. ${ }^{\text {II }}$

\section{Selvmord og kønsforskelle}

I lyset af disse barrierer for korrekt behandling af depression er det også interessant at se nærmere på udbredelsen af selvmord i den arabiske verden. Men da selvmord er et endnu større tabu end depression, er det måske ikke overraskende, at data om forekomsten af selvmord er nærmest ikkeeksisterende.

Men også i denne sammenhæng er psykiatere i Maghreb-landene begyndt at tage livtag med et tabu. Eksempelvis har den marokkanske psykiater, Nadia Kadiri, lavet et omfattende studium af forekomsten af selvmord og selvmordsforsøg i Marokko. Hun fandt, at modsat de fleste marokkaneres forestillinger, er disse fænomener faktisk forholdsvis udbredte. Det mest overraskende resultat af under- 
søgelsen er imidlertid, at selvmord i Marokko er langt hyppigere blandt kvinder end blandt mænd - hvilket er modsat af hvad der er tilfældet i Vesten. Samtidig viser undersøgelsen, at sammen med depression er det at være ugift kvinde eller gift kvinde uden børn de vigtigste indikatorer for selvmord. ${ }^{\text {12 }}$

Mens endogen depression både i Vesten og i den arabiske verden er mest udbredt blandt kvinder, hvilket formodes at skyldes biologiske faktorer, synes der altså med hensyn til selvmord at være sociale forhold der gør sig gældende, og som i Marokko giver en overrepræsentation blandt kvinder. Og flere arabiske psykiatere har de senere år peget på kvinders vilkår i den arabiske verden som afgørende for deres mentale velbefindende. Dette fremgår eksempelvis af en undersøgelse af den tunesiske psykiater Saïda Douki, som viser at de traditionelle livsformer, kvinder i den arabiske verden er underlagt, ofte udgør betragtelige psykiske belastninger. Arrangerede ægteskaber, vold i familien, polygami, mandens ret til ensidigt at kræve skilsmisse og - i Egypten, Djibouti og Mauretanien - kvindelig omskæring har ifølge Douki alvorlige konsekvenser. Også den egyptiske psykiater, Ahmed Okasha, peger på kvinders status i samfundet som en vigtig indikator: Kvinder er som i udgangspunkt mindre værd end mænd. Allerede før sin undfangelse er en pige mindre ønsket af sine forældre end en dreng, og kvindekønnet defineres omkring den reproducerende rolle. Kvinders opgave i livet er udelukkende at føde og opdrage børn, og dermed er deres selvværd og fremtidsperspektiver som udgangspunkt begrænsede. De er dermed allerede som børn underlagt betydelige psykologiske risikofaktorer. ${ }^{13}$
Andre tunesiske psykiatere peger på kvinders undertrykte seksualitet som endnu et vigtigt element: Kvinders fysiske behov for seksuel tilfredsstillelse er ikke anerkendt, og det kønsopdelte samfund og

\section{mom \\ Selvmord i Marokko er langt hyppigere blandt kvinder end moend - hvilket er modsat af tilfoeldet $i$ Vesten.}

manglen på seksualundervisning skaber en egentlig seksuel fobi hos mange kvinder. Hertil kommer kravet om at kunne fremvise mødomsblod på bryllupsnatten, hvilket - sammenholdt med kravet til manden om på sin side at kunne præstere og demonstrere sin virilitet - ofte resulterer $i$ ganske voldsomme oplevelser for kvinden ved hendes seksuelle debut. Alt dette influerer negativt på kvinders seksualitet, og mange kvinder oplever generelt det seksuelle samkvem som forbundet med aggression. ${ }^{\mathrm{I}}$

Endnu andre faktorer, der ifølge jordanske forskere udgør betydelige psykiske belastninger for kvinder i den arabiske verden er den sociale kontrol, hvor mistanke om manglende ærbarhed fra omgivelserne er en konstant trussel, og hvor manglende ægteskab eller manglende børnefødsler er socialt uacceptabelt. Ofte lever gifte kvinder også under samme tag som svigerfamilien, hvilket i ganske mange tilfælde er konfliktfyldt og dermed skaber et konstant psykisk pres på kvinden. ${ }^{15}$

Også saudiske psykologer peger på samfundsstrukturer i den arabiske verden som risikofaktorer for især kvinder. Men i lighed med flere af de andre nævnte kilder 
fremhæver de, at det ikke er islam per se, der er problemet, men derimod den tiltagende nedbrydning af de "rigtige" islamiske familieværdier. Resultatet er ifølge den kvindelige saudiske psykolog, Parisa Saed Al-Hashem, at mange saudiske familier er præget af en giftig stemning og mangel på følelsesmæssig støtte mellem familiemedlemmerne. Samtidig mangler samfundet et socialt netværk, der kan træde til i vanskelige situationer - for eksempel kan kvinder, der udsættes for vold i hjemmet ikke forvente at få hjælp af politiet. Al-Hashem mener desuden, at mange mænd har et "tunnelsyn", der forhindrer dem $i$ at se andet end deres egne, snævre og personlige interesser. Uhensigtsmæssige traditioner er blevet blandet med muslimske værdier, for eksempel misbruges muligheden for polygami, selvom "ingen kvinde selvfølgelig ønsker at dele din mand med en anden, ligesom ingen børn ønsker at se en anden kvinde end deres mor i deres fars liv", siger den saudiske psykolog, som mener, at hvad der er behov for, er "uddannelse, uddannelse og mere uddannelse, så alle er klar over deres rettigheder, pligter og ansvar." ${ }^{16}$

En række undersøgelser, der specifikt afdækker forekomsten af fødselsdepression, dokumenterer også, at dette er mere udbredt $\mathrm{i}$ arabiske lande end i Vesten, og eftersom fænomener som polygami og et negativt forhold til svigermoderen viser sig at være blandt de mest afgørende risikofaktorer, synes den arabiske familiestruktur også i den forbindelse at spille en rolle. Ligeledes ser religiøse anbefalinger af et langvarigt ammeforløb - Koranen og hadith anbefaler amning i barnets første to leveår - ud til at udgøre en reel belastning.
Flere af undersøgelserne peger tillige på, at kvindens forholdsvis ensidige funktion som mor og børneopdrager lægger et særligt pres på hende i forbindelse med graviditet og fødsel. ${ }^{17}$

\section{Perspektiver}

Som det fremgår af ovenstående, er der altså ikke blot en spirende erkendelse i den arabiske verden af, at depression og selvmord er problemer, der også vedrører muslimer. Arabiske psykiatere giver tilmed en lammende kritik af den arabiske traditionelle livsform på baggrund af de psykologiske belastninger, den lægger på arabiske kvinder. Disse psykiatere er selv arabere og muslimer, og inddrager som anført også religiøse fortolkninger i deres fremstillinger i et forsøg på at nuancere kritikken. Flere af dem inddrager således korancitater i deres analyser til forsvar for religionen som sådan - men samtidig som angreb på den traditionelle livsform. Imidlertid vedrører kritikken ikke kun islamiske samfund, men må formodes at gælde alle livsformer, hvor kvinden opfattes som mindre værd, hvor hendes køn begrænser hendes frihed og rettigheder, hvor hendes seksualitet undertrykkes, og hvor hendes opgaver i livet er begrænset til opfostring af børn. Desværre er sådanne livsformer vidt udbredte verden over.

I et kønspolitisk perspektiv er det interessant, at vi her har en forsknings- og medicinsk baseret kritik af kvinders forhold i arabisk samfundsliv. De psykologiske konsekvenser dokumenteres i en række videnskabelige undersøgelser, og at de synes at resultere $i$ en øget forekomst af selvmord blandt kvinder, gør blot problematikken endnu mere alarmerende. Måske kunne disse undersøgelser - der er udført i den 
arabiske verden af muslimske forskere bruges aktivt i debatten om kvinders livsvilkår og muligheder i de arabiske samfund såvel som blandt etniske minoriteter herhjemme. Alle resultaterne peger i samme retning og burde føre til eftertanke hos både traditionalister og kulturrelativister: Det giver simpelt hen ikke mening at forsvare kulturelle livsformer, der er mentalt invaliderende for det ene køn.

\section{- $f \cdot$}

I WHO: http://www.who.org/mental_health, Netpsych.dk: http://www.netpsych.dk/

2 WHO: http://www.who.org/mental_health

3 Visse medicintyper påvirker også noradrenalin- og dopaminbalancen (http://www.psykiatrifonden.dk/)

4 http://www.psykiatrifonden.dk/, Netpsych.dk: http:// www.netpsych.dk/

5 Hamdani, Hassan \& Abdellatif El Aziz: “Être dépressif au Maroc", TelQel Online, nr. I6, Novembre 2005

6 Fx refererer artiklen "Mental depression blamed on breakdown of family values", i Arab News, 9 august 2007 til et saudisk TV-program, hvor problemstillingen behandles. Desuden er en del af baggrundslitteraturen til denne artikel eksempler på journalistiske magasinartikler om emnet.

7 Hamdani, Hassan \& Abdellatif El Aziz: "Être dépressif au Maroc", TelQel Online, nr. I6, Novembre 2005.

8 Hamdi, E. Y. Amin \& M. T. Abou-Saleh: "Problems in validating endogenous depression in the Arab culture by contemporary diagnostic criteria", i Journal of Affect Disorders, vol. 44, nr. 2-3, I997; Hamdi, E. Y. Amin \& M. T. Abou-Saleh: "Performance of the Hamilton Depression Rating Scale in depressed patients in the United Arab Emirates", i Acta Psychiatrica Scandinavica, nr. 6, I997

9 Nasir, Laeth S \& Al-Qutob, Raeda: "Barriers to the diagnosis and treatment of depression in Jordan", i JABFP March-April 2005, vol. I8, nr. 2.

Io Hamdani, Hassan \& Abdellatif El Aziz: "Être dépressif au Maroc", TelQel Online, nr. I6, novembre 2005 .

II Touhami, Mekki: "Psychothérapies et prise en charge traditionnelle", i Revue Maghrébine de Psychiatrie, 23 mars 2005; Al-Atouabi, Majdouline: "Voyage au bout de la folie", i Maroc Hebdo International nr. 639, II-I6 février 2005 .

I2 Haimoud, Atika: Kadiri: "la dépression peut mener au suicide”, i Aujourd'hui Le Maroc, nr. 9, Septembre 2005, Boudarham, Mohamed: La fascination pour la mort. Aujourd'hui Le Maroc, 9 Septembre 2005.
I3 Véran, Sylvie: "L'Islam, la femme et le psychiatre. Tempête sous le voile", i Nouvel Observateur, 26 juillet 200 I

I4 Véran, Sylvie: "L'Islam, la femme et le psychiatre. Tempête sous le voile", i Nouvel Observateur, 26 juillet $200 \mathrm{I}$

I5 Nasir, Laeth S \& Al-Qutob, Raeda: "Barriers to the diagnosis and treatment of depression in Jordan", i JABFP March-April 2005, vol. I8, nr. 2.

I6 "Mental depression blamed on breakdown of family values", i Arab News, 9 August 2007.

I7 Green, Katherine; Hazel Broom \& James Mirabella: "Postnatal depression among mothers in the United Arab Emirates: Socio-cultural and physical factors, i Psychology, Health \& Medicine, vol. II, nr. 4, 2006; Chaaya, M. et. al.: Postpartum depression: Prevalence and determinants in Lebanon, i Archive of Women's Mental Health, vol. 5, 2002; Abu-Saleh, M.T. \& Ghubash, R.: The prevalence of postpartum psychiatric morbidity in Dubai: A transcultural perspective, i Acta Psychiatrica Scandinavica, vol. 95, I997. 